\title{
Efficient Method for Isolation of High-Quality RNA from Psidium Guajava L. Tissues
}

Paola Avelar Carpinetti ( $\sim$ paolacarpinetti@alumni.usp.br )

Universidade Federal do Espirito Santo https://orcid.org/0000-0001-8728-6344

\section{Vinicius Sartori Fioresi}

Universidade Federal do Espírito Santo

\section{Thais Ignez Cruz}

Universidade Federal do Espirito Santo

Francine Alves Nogueira Almeida

Universidade Federal do Espirito Santo

Drielli Canal

Universidade Federal do Espirito Santo

Adésio Ferreira

Universidade Federal do Espírito Santo

Marcia Flores da Silva Ferreira

Universidade Federal do Espírito Santo

\section{Methodology}

Keywords: RNA, guava, Psidium guajava, Myrtaceae, isolation method, CTAB

Posted Date: November 5th, 2020

DOI: https://doi.org/10.21203/rs.3.rs-100936/v1

License: (c) (i) This work is licensed under a Creative Commons Attribution 4.0 International License. Read Full License

Version of Record: A version of this preprint was published at PLOS ONE on July 26th, 2021. See the published version at https://doi.org/10.1371/journal.pone.0255245. 


\section{Title: Efficient method for isolation of high-quality RNA from Psidium}

\section{2 guajava L. tissues}

3 Authors: Paola de Avelar Carpinetti ${ }^{1 \S}$, Vinícius Sartori Fioresi ${ }^{1 \S}$, Thais Ignez da Cruz ${ }^{1}$,

4 Francine Alves Nogueira de Almeida ${ }^{1}$, Drielli Canal ${ }^{1}$, Adésio Ferreira ${ }^{1}$, Marcia Flores da

$5 \quad$ Silva Ferreira ${ }^{1}$

6

$7 \quad{ }^{1}$ Laboratório de Genética e Melhoramento Vegetal, Departamento de Agronomia, Centro

8 de Ciências Agrárias e Engenharias, Universidade Federal do Espírito Santo. ZIP: 29.500-

9000 Alegre - ES, Brazil.

$10 \S$ : Both authors contributed equally to this work.

12 Corresponding author: e-mail: paolacarpinetti@alumni.usp.br

Tel.: +55 (28) 3552-8678

15 Abstract

Background: Acquiring high-quality RNA in sufficient amounts is necessary in plant molecular biology and genetic studies. Several methods of RNA extraction from plants are available in the literature, mainly due to the great biochemical diversity present in each species and tissue, which can complicate or prevent the extraction. Psidium guajava (Myrtaceae family) is a perennial fruit tree of medicinal and economic value; nevertheless, only few molecular and omics studies are available for the species. One reason for this fact is the difficulty in obtaining the RNA due to the content of the samples, which are rich in polyphenols, polysaccharides and secondary metabolites. Furthermore, 
there is still no tested or standardized method available for the isolation of RNA from guava or Psidium samples, which hampers advances in the genus.

Results: Here we compare the quality and yields of RNA isolated using six extraction protocols: two based on the application of cetyltrimethylammonium bromide (CTAB) lysis buffer, two commercial kits (PureLink ${ }^{\mathrm{TM}}$ RNA Mini Kit and RNeasy ${ }^{\circledR}$ Plant Mini Kit), one using the TRIzol ${ }^{\circledR}$ reagent, and one applying guanidine thiocyanate lysis buffer followed by organic phase extraction. RNA integrity, quality and yields were assessed by agarose gel electrophoresis and spectrophotometry. The CTAB-based method provided the highest RNA yields and quality for five different tissues (flower bud, immature leaf, young leaf, mature leaf and root), genotypes and stress conditions.

For the most efficient protocol, the average yield of RNA from guava leaf was $210.4 \mu \mathrm{g} / \mathrm{g}$ of tissue, and the $A_{260} / A_{280}$ and $A_{260} / A_{230}$ ratios were 2.1 and 2.2, respectively. $R T$-PCR analysis demonstrated that the purity of the samples was sufficient for molecular biology experiments.

Conclusion: CTAB-based methods for RNA isolation were found to be the most efficient, providing the highest RNA yields and quality for tissues from P. guajava. Additionally, they demonstrated to be compatible for downstream RNA-based applications, besides showing the advantages of lower cost and time investments.

Keywords: RNA, guava, Psidium guajava, Myrtaceae, isolation method, CTAB.

\section{Background}

Advances in the knowledge of cell and molecular biology - such as the discovery of genes, underlying mechanisms of gene regulation, signal transduction and the factors involved in phenotypic characteristics - require a whole range of techniques, such as 
northern hybridization, reverse transcription, polymerase chain reaction (PCR), construction of cDNA libraries, and sequencing. Obtaining high RNA quality and yields is fundamental for the execution and success of these approaches. The isolation of intact RNA is difficult due to the chemical nature of the RNA molecule, which is more susceptible to hydrolysis, and its sensitivity to enzymatic degradation by ribonucleases (RNases), which are very active, widespread, stable, and require no-cofactors $[1,2]$. Furthermore, the isolation and purification of high-quality RNA from plant tissues in sufficient amounts has been reported to be difficult in samples rich in polyphenols, polysaccharides and other secondary metabolites that interfere with the quantification and subsequent applications [3-7].

Guava (Psidium guajava L., family Myrtaceae) is an important commercial fruit crop cultivated in tropical and subtropical regions of the world. The largest producer countries are India, China, Thailand, Pakistan, Mexico, Indonesia and Brazil, respectively [8]. Different parts of the plant are rich in nutrients and functional elements, such as antioxidants, vitamin C, potassium and fiber [9, 10]. It is also widely used for medicinal purposes owing to its healing, anti-allergic, anti-diabetic, anti-diarrheal, anti-neoplastic, anti-inflammatory and anti-microbial properties [11-17]. Although relevant knowledge is available about the species' biochemical composition, benefits and applications, when compared to other crops, genetic and genomic studies in guava are incipient. Developments in the genetic analysis and functional genomics of guava could complement the conventional breeding process, leading to improvement of crop productivity and addressing the challenges of enhancing fruit quality and tolerance to abiotic and biotic stresses [18-20]. However, the success of many downstream RNAbased applications relies on obtaining high-quality RNA. 

was originally described in 1953 for bacterial samples [21]. Since then, this protocol has

been extensively used and modified for the extraction of DNA and RNA from several species [22-26]. In recent years, CTAB-based methods have been used for nucleic acid isolation from many plant species, especially those containing a high level of phenolic compounds and polysaccharides [3, 27-29]. Most of the popular RNA isolation protocols are based on guanidine salts, such as the reagent TRIzol ${ }^{\circledR}$ (Invitrogen, USA) and commercial kits like RNeasy $^{\circledR}$ (QIAGEN, Germany) and PureLink ${ }^{\mathrm{TM}}$ RNA (Invitrogen, USA). Although this method has been used successfully for the isolation of RNA from tissues of a variety of plants [30-34], for other species, protocols based on the guanidine method have proven to be unable to isolate quality RNA with satisfactory yields; besides, they increase the chances of co-purifying contaminants, which interferes with downstream applications $[7,35,36]$.

The present study was motivated by the lack of knowledge about which methods are efficient for the extraction of sufficient quantities of high-quality RNA from $P$. guajava, mainly for use in studies of gene expression and omics analyses. Here, we examined the use of two extraction buffers based on a cationic surfactant, CTAB, and four methods using chaotropic lysis buffers containing guanidine thiocyanate. In the guanidine group, two commercial kits that use silica membrane to isolate RNA were evaluated, the PureLink ${ }^{\mathrm{TM}}$ RNA Mini Kit and the RNeasy ${ }^{\circledR}$ Plant Mini Kit. The third method is based on the association of lysis buffer with phenol-chloroform, the TRIzol ${ }^{\circledR}$ reagent. The last protocol in this group is the guanidine thiocyanate method, the only already described for the isolation of $P$. guajava RNA [37]. Our goal was to identify an efficient RNA isolation method for various $P$. guajava tissues that can be used in plant molecular biology studies. 
Results and Discussion

RNA isolation plays an important role in various experiments in plant molecular

biology, such as gene expression and transcriptomics. However, obtaining RNA with

enough quality and quantity may be a great challenge, mainly for plant species, since their

biochemical composition can hinder and even prevent the extraction. Besides, due to the rich variety of cellular chemical contents of plants, there are no standard methods for the isolation of RNA applicable to all plant species. Members of the Myrtaceae family are characterized by abundance of essential oils rich in terpenes, tannins, phenolic compounds, polysaccharides and other secondary metabolites that hinder the extraction molecular studies for the species of this family.

In this study, six RNA isolation methods were compared, and the success of each protocol was judged by the quantity, purity and integrity of the recovered RNA. Figure 1 shows the outcomes for RNA integrity, assessed by agarose gel electrophoresis. For $\mathrm{CTAB}_{1}$ and 2 as well as the guanidine thiocyanate protocols, distinct $28 \mathrm{~S}$ and $18 \mathrm{~S}$ rRNA bands were visible, with high brightness and no obvious smearing due to degradation, $0.03), \mathrm{CTAB}_{2}(2.13 \pm 0.04)$ and the guanidine thiocyanate protocols $(1.95 \pm 0.14)$ indicated that these methods were efficient in preventing mainly protein contamination. 
122 On the other hand, for TRIzol ${ }^{\circledR}$, the RNeasy ${ }^{\circledR}$ Plant Mini Kit and the PureLink ${ }^{\mathrm{TM}}$ RNA

123 Mini Kit protocols, the low values indicate that there were problems in the extraction and

124 a substantial amount of proteins precipitated with the nucleic acid. Importantly, with

125 regard to the ratio $\mathrm{A}_{260} / \mathrm{A}_{230}$, only $\mathrm{CTAB}$-based protocols showed values that correspond

126 to high purity $(2.24 \pm 0.33$ and $2.24 \pm 0.07)$. The other samples showed high absorbance

127 at $230 \mathrm{~nm}$, a wavelength at which carbohydrates, phenols and aromatic compounds

128 generally absorb.

129

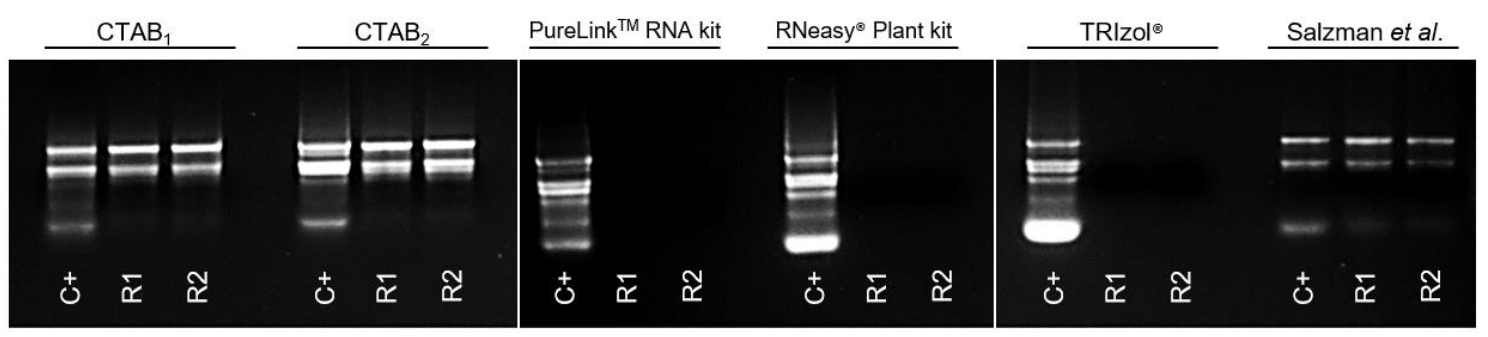

Figure 1 - Qualitative analysis of RNA by electrophoresis. Denaturing agarose gel

(1\%) electrophoresis of total extracted RNA $(2 \mu \mathrm{L})$ stained with GelRed ${ }^{\circledR}$ (Biotium,

USA). For the positive control $(\mathrm{C}+)$, total RNA was extracted from soybean (Glycine

max) leaves, and extractions using $P$. guajava leaves were performed in duplicate (R1 and R2).

Table 1 - Analysis of RNA yield and purity for different methods

\begin{tabular}{|c|c|c|c|c|}
\hline Method & $\mathbf{n}$ & Yield $(\mathrm{ng} / \mu \mathrm{L})$ & $\mathbf{A}_{260} / \mathbf{A}_{280}$ ratio & $\mathbf{A}_{260} / A_{230}$ ratio \\
\hline $\mathrm{CTAB}_{1}$ & 6 & $384.15 \pm 69.35$ & $2.10 \pm 0.03$ & $2.24 \pm 0.33$ \\
\hline $\mathrm{CTAB}_{2}$ & 6 & $701.27 \pm 191.96$ & $2.13 \pm 0.04$ & $2.24 \pm 0.07$ \\
\hline PureLink ${ }^{\mathrm{TM}}$ RNA Kit & 5 & $140.45 \pm 32.13$ & $1.00 \pm 0.20$ & $0.25 \pm 0.06$ \\
\hline RNeasy ${ }^{\circledR}$ Plant Kit & 6 & $33.20 \pm 6.92$ & $1.18 \pm 0.14$ & $0.17 \pm 0.05$ \\
\hline TRIzol $^{\circledR}$ reagent & 6 & $447.95 \pm 134.98$ & $1.09 \pm 0.13$ & $0.41 \pm 0.10$ \\
\hline Guanidine thiocyanate & 6 & $445.80 \pm 257.13$ & $1.95 \pm 0.14$ & $1.63 \pm 0.26$ \\
\hline
\end{tabular}

The values correspond to the median of the values and MAD (median absolute deviation) obtained 

quantifications obtained by spectrophotometry shown in Table 1 . The RNA concentrations of the samples were obtained by evaluating the absorbance at $260 \mathrm{~nm}$ $\left(\mathrm{A}_{260}\right)$. In this analysis, the RNA samples from $\mathrm{CTAB}_{2}$ had the highest yields, $210.4 \pm$ $57.6 \mu \mathrm{g}$ of RNA for each gram of leaf tissue. $\mathrm{CTAB}_{1}$ and the guanidine thiocyanate methods also provided good yields $(115.25 \pm 20.81$ and $133.74 \pm 77.14$, respectively). However, the yield of the guanidine-based method is possibly not accurate, since the intensity of the rRNA bands is weaker than in the $\mathrm{CTAB}_{1}$ method. This may be a reflection of contaminants present in the guanidine thiocyanate samples, evidenced by the absorb in the $260 \mathrm{~nm}$ range, thus distorting the quantification. The same occurred in samples extracted with TRIzol ${ }^{\circledR}$, which showed great absorption at $\mathrm{A}_{260}$, but presented very low $\mathrm{A}_{260} / 280$ and $\mathrm{A}_{260} / 230$ ratios $(1.09 \pm 0.13$ and $0.41 \pm 0.10)$ and no visible bands in the agarose gel. Additionally, both evaluated commercial kits failed to isolate RNA from P. guajava leaves, as demonstrated by the low obtained yields and the analysis of $\mathrm{A}_{260} / 280$ and $\mathrm{A}_{260} / 230$ ratios indicating great contamination of the samples.

The comparative evaluation of these results allowed to determine that CTABbased methods were more efficient for isolating RNA from $P$. guajava leaves, whereby the $\mathrm{CTAB}_{2}$ protocol was the most efficient, isolating RNA with high purity, integrity and yields. These findings are compatible with other studies which demonstrated that methods based on guanidine salts, TRIzol ${ }^{\circledR}$ and commercial kits were not effective for extracting RNA from species rich in secondary metabolites [4, 7, 35]. The CTAB-based methodology has also been used successfully by Jaakola et al. (2001) for the extraction of high-quality RNA from Vaccinium myrtillus [40], and by Zeng \& Yang (2002) in Cinnamomum tenuipilum [29], both perennial tree species. More recently, researchers of 
species from the Myrtaceae family have isolated RNA by the CTAB method and performed analyses of transcriptome and gene expression, such as Guzman et al. (2014) in Eugenia uniflora [41], and Vining et al. (2015) and Favreau et al. (2019) in Eucalyptus grandis [42, 43]. In the study involving P. guajava, Furlan et al. (2012) isolated RNA using the guanidine thiocyanate buffer evaluated in this study [37]. However, in the comparative analysis, this method did not show the best results.

Guava samples have a high content of polyphenols, polysaccharides, tannins, among other metabolites that may interfere with the RNA isolation [44, 45]. In solution, phenolic compounds are easily oxidized to form quinones, which can bind to the RNA and render it insoluble, hindering the RNA isolation and/or downstream applications [45]. During extraction, polysaccharides produce saccharide fragments that may be co-purified with the RNA, owing to their chemical characteristics being very similar to nucleic acids $[44,46]$. The greater efficiency of the extraction by the CTAB method may be related to the composition of the respective lysis buffer. CTAB is a cationic surfactant, acting as a strong detergent to help break membranes and separate the nucleic acids from polysaccharides and cellular debris [47]. The oxidation of polyphenols is prevented by the use of soluble polyvinylpyrrolidone polymers (PVP) that immediately bind to those compounds, and this preclude the formation of quinones and their binding to RNA [40]. Also heating of the extraction buffer with a relatively high concentration of $\beta$ mercaptoethanol promotes more efficient tissue disruption, removal of tannins and polysaccharides, and prevention of RNase activity [48, 49]. Carbohydrate contamination is reduced by the use of $\mathrm{LiCl}$ in the precipitation step, since the saccharides remain in solution while the RNA precipitation occurs [48].

It is known that the composition varies greatly between tissues, not less under stress conditions, owing to the physiological metabolism and remodeling of pathways for 
the stress response. Moreover, isolating RNA of adequate quality from tissues exposed to stressful conditions such as salinity and heavy metal toxicity is difficult due to increased accumulation of reactive oxygen species (ROS), secondary metabolites and other compounds that easily degrade nucleic acids or promote chemical changes in nucleic acids that hinder isolation $[50,51]$. With the aim of expanding the analysis and verifying the usefulness of the proposed protocol, we also evaluated the ability of the $\mathrm{CTAB}_{2}$ protocol to gain RNA from different $P$. guajava tissues (Figure 2 and Table 2), from tissues under salt and cadmium stress conditions (Table 2), and from another species of the same genus, Psidium guineense (Supplementary information - S1).

In summary, the proposed protocol provided high RNA yields, quality and purity in the assessed tissues and conditions. Even in developing tissues, such as flower buds, which usually accumulate high amounts of secondary metabolites and have been reported with low quality [52], in this study, good yields and quality were observed. The best results were obtained for the immature leaf and root tissues, evidenced mainly by the analysis using TapeStation ${ }^{\circledR}$ capillary electrophoresis (Figure 2.B), in which these samples presented RIN (RNA Integrity Number) [53] of 7.2 and 8.8, respectively. For leaf samples from plants under salt and cadmium stress (Table 2), reduction in yield was observed; however, this result was already expected, since these treatments can induce the degradation of nucleic acids as a result of the cell death trigger as well as shift in the chemical content $[54,55]$.

The presence of contaminants in samples not only hampers the isolation and quantification of the RNA, but may also interfere with the activity of some enzymes, such as reverse transcriptase in the synthesis of cDNA and DNA polymerase in PCR. Substances used in extraction techniques, such as ethanol, phenol, chloroform and salts, are described to inhibit these enzymes and consequently impair these techniques. 

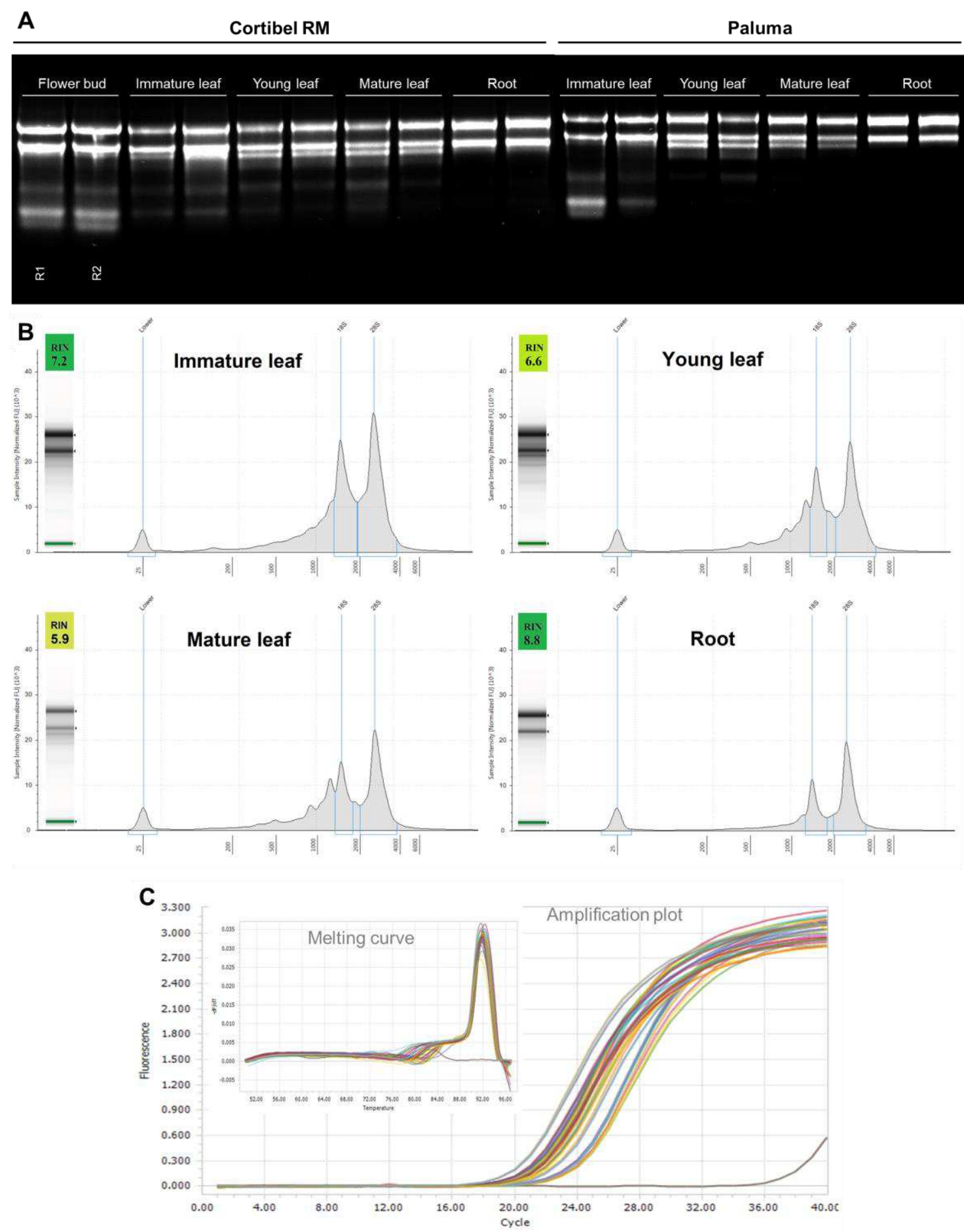

213 Figure 2 - Qualitative analysis of RNA from different tissues. (A) Denaturing agarose

214 gel (1\%) electrophoresis of total extracted RNA $(2 \mu \mathrm{L})$ stained with GelRed $^{\circledR}$ (Biotium,

215 USA). Extractions using the $\mathrm{CTAB}_{2}$ protocol were done in duplicate (R1 and R2) for different tissues from two distinct genotypes of P. guajava, Cortibel RM and Paluma. (B) 
217 Quality analysis of RNA samples by TapeStation ${ }^{\circledR}$ (Agilent Technologies, USA) using

218 RNA ScreenTape ${ }^{\circledR}$ assay, after DNase I treatment, and RIN (RNA Integrity Number)

219 were calculated. (C) Quality check of cDNA from $\mathrm{CTAB}_{2}$ samples (Cortibel RM tissues)

220 by amplification of histone $\mathrm{H} 2 \mathrm{~A}$ gene measured using $\mathrm{SYBR}^{\circledR}$ Green qRT-PCR, and

221 melting curve showing specific amplification products.

Table 2 - Analysis of RNA yield and purity using $\mathrm{CTAB}_{2}$ method

RNA yield and purity for different tissues

\begin{tabular}{|c|c|c|c|c|c|c|c|c|}
\hline \multicolumn{2}{|r|}{ Tissue } & \multirow{2}{*}{$\frac{\mathbf{n}}{4}$} & \multicolumn{2}{|c|}{ Yield $(\mathrm{ng} / \boldsymbol{\mu L})^{*}$} & \multicolumn{2}{|c|}{$\mathrm{A}_{260} / \mathrm{A}_{280}$ ratio $^{*}$} & \multicolumn{2}{|c|}{$\mathbf{A}_{260} / \mathbf{A}_{230}$ ratio } \\
\hline \multirow{5}{*}{ 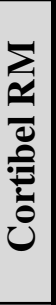 } & Flower bud & & 2325.10 & \pm 520.53 & 2.08 & \pm 0.13 & 2.28 & \pm 0.07 \\
\hline & Immature leaf & 12 & 1004.48 & \pm 184.14 & 2.15 & \pm 0.04 & 2.21 & \pm 0.08 \\
\hline & Young leaf & 12 & 759.94 & \pm 64.63 & 2.14 & \pm 0.01 & 2.33 & \pm 0.05 \\
\hline & Mature leaf & 12 & 539.02 & \pm 88.87 & 2.11 & \pm 0.04 & 2.40 & \pm 0.07 \\
\hline & Root & 12 & 618.77 & \pm 118.68 & 2.19 & \pm 0.03 & 2.55 & \pm 0.35 \\
\hline \multirow{4}{*}{ 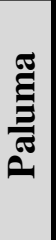 } & Immature leaf & 12 & 842.80 & \pm 248.90 & 2.14 & \pm 0.03 & 2.24 & \pm 0.10 \\
\hline & Young leaf & 12 & 775.80 & \pm 110.69 & 2.17 & \pm 0.04 & 2.31 & \pm 0.06 \\
\hline & Mature leaf & 12 & 358.74 & \pm 67.82 & 2.22 & \pm 0.03 & 2.32 & \pm 0.07 \\
\hline & Root & 12 & 274.49 & \pm 31.53 & 2.21 & \pm 0.02 & 2.53 & \pm 0.10 \\
\hline
\end{tabular}

RNA yield and purity for stressed leaves from different $P$. guajava genotypes

\begin{tabular}{|c|c|c|c|c|c|}
\hline & Genotype & $\mathbf{n}$ & Yield $(\mathrm{ng} / \mu \mathrm{L})^{\#}$ & $\mathbf{A}_{260} / \mathbf{A}_{280}$ ratio $^{\#}$ & $\mathbf{A}_{260} / \mathbf{A}_{230}$ ratio $^{\#}$ \\
\hline \multirow{5}{*}{$\begin{array}{l}\bar{o} \\
\stackrel{\Xi}{0} \\
\dot{0}\end{array}$} & Paluma & 6 & $629.95 \pm 102.41$ & $2.25 \pm 0.07$ & $2.40 \pm 0.21$ \\
\hline & Cortibel LG & 6 & $749.24 \pm 298.81$ & $2.22 \pm 0.02$ & $2.37 \pm 0.04$ \\
\hline & Cortibel RG & 6 & $622.35 \pm 43.88$ & $2.20 \pm 0.02$ & $2.36 \pm 0.01$ \\
\hline & Cortibel RM & 4 & $681.24 \pm 87.74$ & $2.21 \pm 0.02$ & $2.36 \pm 0.07$ \\
\hline & Cortibel XIII & 4 & $805.02 \pm 450.30$ & $2.17 \pm 0.03$ & $2.24 \pm 0.08$ \\
\hline \multirow{3}{*}{ 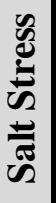 } & Paluma & 6 & $615.00 \pm 52.30$ & $2.15 \pm 0.01$ & $2.33 \pm 0.05$ \\
\hline & Cortibel LG & 6 & $633.40 \pm 102.98$ & $2.18 \pm 0.03$ & $2.38 \pm 0.06$ \\
\hline & Cortibel RG & 6 & $601.74 \pm 152.71$ & $2.15 \pm 0.01$ & $2.10 \pm 0.02$ \\
\hline \multirow{2}{*}{ ن } & Cortibel RM & 3 & $204.59 \pm 146.71$ & $2.09 \pm 0.08$ & $1.88 \pm 0.38$ \\
\hline & Cortibel XIII & 4 & $219.99 \pm 87.43$ & $2.08 \pm 0.09$ & $2.06 \pm 0.23$ \\
\hline
\end{tabular}

* The values correspond to the median of the values and MAD (median absolute deviation) obtained between the replicates $(\mathrm{n})$ of each condition in two independent experiments.

\# The values correspond to the mean of the values and SD (standard deviation) obtained between the replicates 
223 However, inherent substances in the sample, such as polyphenols and polysaccharides can also co-precipitate with the RNA and affect downstream applications [56-61]. In that regard, to ascertain the quality of the samples for applications in molecular biology, samples of four different tissues (immature leaf, young leaf, mature leaf and root) were also evaluated via qRT-PCR. All assessed samples showed a characteristic amplification curve and unique peaks in the melting analysis, demonstrating their adequate quality for molecular biology studies (Figure 2C).

In addition, to further investigate the differences between the CTAB protocols, the presence of inhibitors in the samples was inferred by quantitative analysis via qRTPCR. Linear regression curves based on two-fold serial dilutions containing prepared cDNA synthesized from the same volume of RNA $(5 \mu \mathrm{L})$ were used for all samples. This care was taken to enable comparing the interference of the contaminants in the samples, in which the prevalent is the sample volume that directly impacts the inhibitor concentration. On average, $1 \mu \mathrm{L}$ of cDNA contained $100 \mathrm{ng}( \pm 25 \mathrm{ng})$. From the cycle threshold $(\mathrm{Ct})$ values obtained by amplification of the Histone H2A gene, a linear equation was generated for each sample. Under ideal conditions, each amplification cycle duplicates the cDNA content, and the efficiency of the reaction is said to be one hundred percent. However, especially for samples obtained from plants, without an additional purification step the presence of contaminants is very frequent [62].

Figure 3 shows the graphs for all samples. The effect of PCR inhibition is reflected on the distance between the dots and lines (linear equation) and the obtained values (black) as well as the ideal values (gray). From these results, it can be inferred that all samples present some level of DNA polymerase inhibition, and the interference is slightly more accentuated in $\mathrm{CTAB}_{2}$ than in $\mathrm{CTAB}_{1}$ samples. 

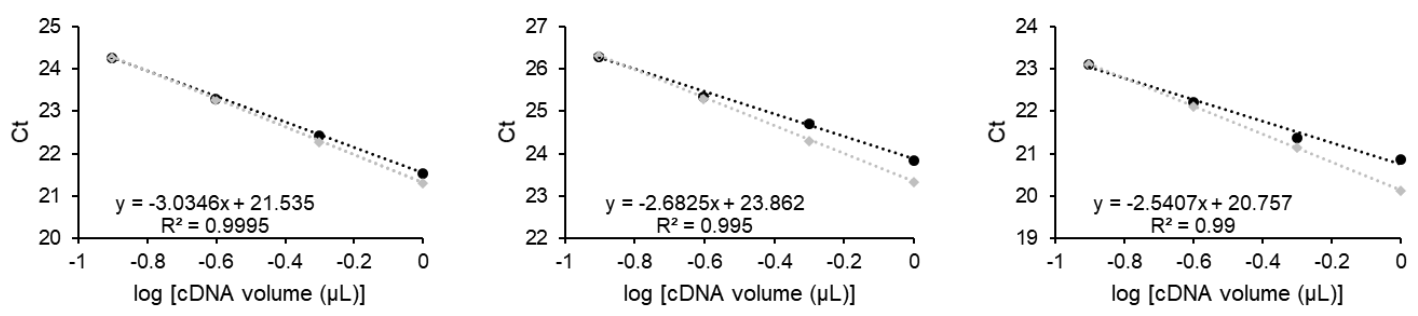

$\mathrm{CTAB}_{1}$-D

$\mathrm{CTAB}_{1}-\mathrm{E}$
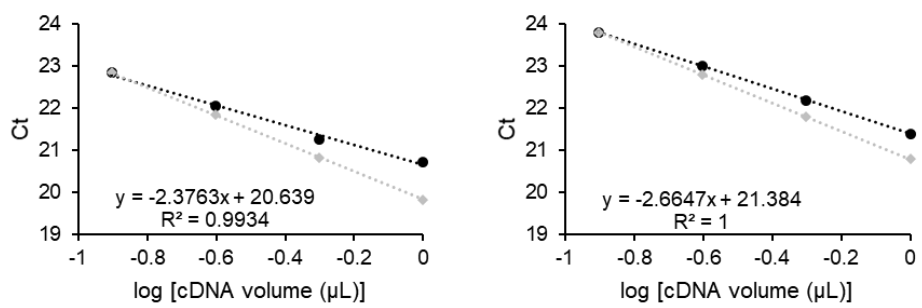

$\mathrm{CTAB}_{1}-\mathrm{F}$

$\mathrm{CTAB}_{2}-\mathrm{A}$

$\mathrm{CTAB}_{2}$-B
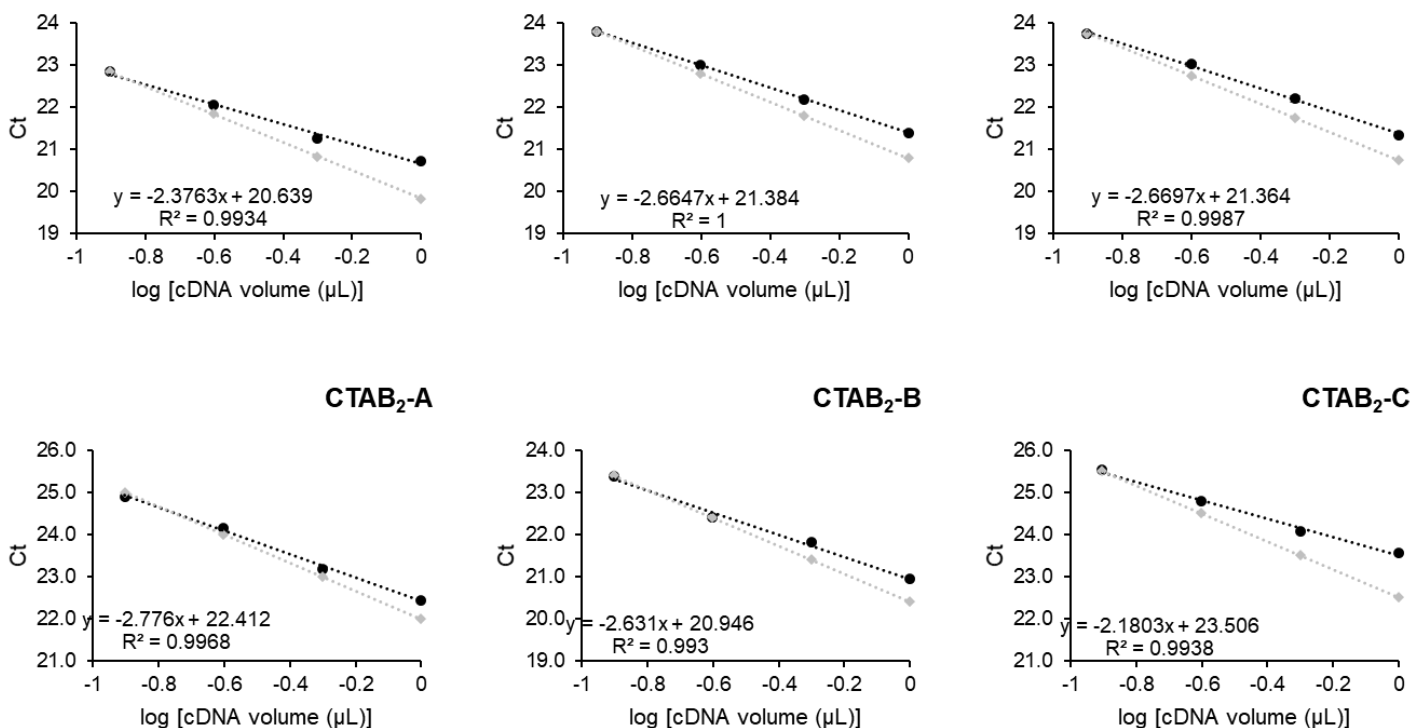

$\mathrm{CTAB}_{2}-\mathrm{C}$

CTAB $_{2}$-D

$\mathrm{CTAB}_{2}-\mathrm{E}$

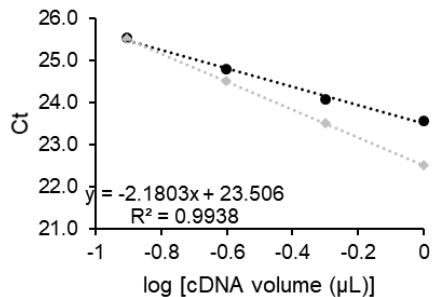

$\mathrm{CTAB}_{2}-\mathrm{F}$
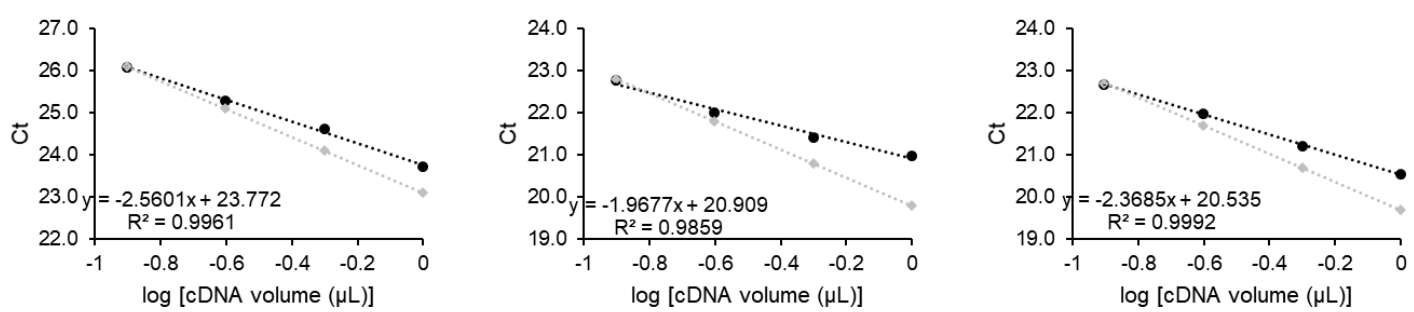

Figure 3 - Quantitative analysis by qRT-PCR to compare CTAB methods. Linear

regression curves of the real-time reverse transcription polymerase chain reaction assay based on serial dilutions of cDNA $(1.0,0.5,0.25$ and $0.125 \mu \mathrm{L})$ synthesized from the same volume of RNA $(5 \mu \mathrm{L})$ were used for all samples. The log of cDNA volume $(\mu \mathrm{L})$

252 is indicated on the $\mathrm{x}$-axis, whereas the corresponding $\mathrm{Ct}$ values are shown on the $\mathrm{y}$-axis.

253 Each dot represents the mean result of three replicates. The correlation coefficient $\left(\mathrm{R}^{2}\right)$ and linear equation of the regression analysis are shown. Values obtained in this assay for each sample are represented in black and ideal values in gray, estimated based on the $\mathrm{Ct}$ 
values of the highest dilution, considering an efficiency of one hundred percent in each cycle.

These effects probably reflect competitive inhibition, since dilution of the samples was followed by reduction of interference. It is also worth mentioning that, although the $\mathrm{CTAB}_{2}$ protocol apparently shows a greater amount or greater inhibitory effect, it will most likely not hamper the qRT-PCR analysis, which can be explained by a few aspects. First, as indicated by analysis of the square of the correlation coefficient $\left(\mathrm{R}^{2}\right)$, the contamination follows a linear regression. Second, the amount usually applied in the PCR reaction is between 30-10 ng per reaction and, for this range, the values obtained are very close to the ideal. Lastly, although the samples for this test were selected within the same concentration range (Supplementary information S2), those obtained using $\mathrm{CTAB}_{2}$ are consistently more concentrated, as already discussed and presented in Table 2 . Thus, in each PCR reaction, in order to apply the same amount of template, the sample must be further diluted, which will additionally minimize this effect of contaminants.

\section{Conclusion}

In the present study, we compared six RNA isolation methods, and CTAB-based protocols were found to be the most efficient, providing the highest RNA yields and quality for different tissues, genotypes, and under stress conditions. Additionally, we demonstrated that samples are compatible for downstream RNA-based applications, besides showing the advantages of lower cost and time investments. From that knowledge, we hope to contribute to the increase and quality of molecular genetic studies for Psidium guajava the related species. 


\section{Plant Material}

Clonal seedlings of Psidium guajava (Paluma and Cortibel RM genotypes) were obtained from the Frucafé Nursery, accredited by the Brazilian Ministry of Agriculture. The specimens used in this study were obtained and maintained in healthy conditions in a greenhouse.

For the comparison of protocols, six leaf discs with diameter of $0.8 \mathrm{~cm}(70-100$ mg) were collected from young leaves of the Paluma genotype when the plants were approximately 100 days old. Each sample represented a pool of tissues obtained from three different plants. All collected biological material was immediately frozen in liquid nitrogen and subsequently stored in an ultra low temperature (ULT) freezer at $-80^{\circ} \mathrm{C}$.

To evaluate the efficiency of RNA isolation in different tissues and genotypes, flower bud, immature leaf, young leaf, mature leaf and root from the Cortibel RM genotype and immature leaf, young leaf, mature leaf and root from the Paluma genotype were used (Supplementary information - S3). Approximately $100 \mathrm{mg}$ (80-110 mg) of tissue were used for each sample, except the root, for which $200 \mathrm{mg}$ of tissue were used.

\section{RNA Isolation}

All reagents were prepared in RNase-free ultrapure water, and glasses, mortars and pestles were treated with $1 \mathrm{M} \mathrm{NaOH}$, autoclaved, and then baked overnight at $60^{\circ} \mathrm{C}$. At least five extractions were performed for each protocol, as well as two extractions with soybean (Glycine $\max$ ) as positive control. All samples were extracted starting from the same material and in the same quantity. The tissue samples were ground in liquid nitrogen using a porcelain mortar $(60 \mathrm{~mL})$ until becoming a fine powder. Care was taken to ensure 
that the material did not thaw in this process. The extraction buffer corresponding to each method was added to samples of the obtained tissue powder.

\section{Cetyltrimethylammonium Bromide (CTAB)-based Methods}

Extraction buffer: 2\% CTAB, 2\% PVP (mol wt 30,000), 100 mM Tris-HCl (pH 8.0), 25 mM EDTA, $2 \mathrm{M} \mathrm{NaCl}, 0.05 \%$ spermidine trihydrochloride, 2\% $\beta$-mercaptoethanol (added just before use).

\section{CTAB Protocol $1\left(\mathrm{CTAB}_{1}\right)$ :}

This CTAB protocol was initially adapted by Zeng and Yang (2002) and minor modifications were made here, such as reducing the amount of starting material. Briefly, $900 \mu \mathrm{L}$ of extraction buffer were heated at $65^{\circ} \mathrm{C}$ and added to a mortar containing the sample ( 100 mg, powdered in liquid nitrogen as described above), then transferred to a $2.0 \mathrm{~mL}$ microtube, and vigorously shaken several times. The mixture was incubated at $65^{\circ} \mathrm{C}$ for 10 min under shaking. Next, an equal volume of chloroform/isoamyl alcohol $(24: 1, \mathrm{v} / \mathrm{v})$ was added and the microtube was vigorously mixed. The tube was centrifuged at $10,000 \times g$ for $10 \mathrm{~min}$ at $4^{\circ} \mathrm{C}$. The supernatant was recovered and transferred to a new $1.5 \mathrm{~mL}$ microtube and re-extracted with an equal volume of chloroform/isoamyl alcohol ( $650 \mu \mathrm{L})$. The supernatant was slowly and carefully collected to avoid contamination, and a new centrifugation was performed at $25,000 \times g$ for $30 \mathrm{~min}$ at $4{ }^{\circ} \mathrm{C}$ to sediment and discard the insoluble material. To precipitate the RNA, 0.5 volume of $5 \mathrm{M} \mathrm{LiCl}$ was added to the supernatant, mixed well, and the tube was subsequently incubated at $4^{\circ} \mathrm{C}$ overnight. The RNA pellet was obtained by centrifugation at $25,000 \times g$ for $30 \mathrm{~min}$ at $4^{\circ} \mathrm{C}$. The supernatant was discarded, and the pellet was washed three times with $75 \%(\mathrm{v} / \mathrm{v})$ ethanol 
and centrifuged at $10,000 \times g$ for $20 \mathrm{~min}$ at $4^{\circ} \mathrm{C}$. The pellet was dried at room temperature and solubilized in $30 \mu \mathrm{L}$ of RNase-free ultrapure water. The extracted RNA was stored in an ULT freezer at $-80^{\circ} \mathrm{C}$ for subsequent analyses.

\section{CTAB Protocol $2\left(\mathrm{CTAB}_{2}\right)$ :}

This CTAB protocol was adapted by Guzman et al. (2014), and here the initial sample amount was reduced from $150 \mathrm{mg}$ to $100 \mathrm{mg}$ of tissue, besides minor changes to some procedures. Initially, $900 \mu \mathrm{L}$ of pre-warmed extraction buffer $\left(65^{\circ} \mathrm{C}\right)$ was added to mortar containing tissue powder, and the mixture was stirred until becoming homogeneous. The mixture was then transferred to a $2 \mathrm{~mL}$ microtube and incubated at $65^{\circ} \mathrm{C}$ for $10 \mathrm{~min}$. Next, an equal volume of chloroform/isoamyl alcohol (24:1, v/v) was added and the tube was vigorously mixed. The microtube was centrifuged at $7,000 \times g$ for $20 \mathrm{~min}$ at $4^{\circ} \mathrm{C}$. The supernatant was recovered and transferred to a new $1.5 \mathrm{~mL}$ microtube, then re-extracted with an equal volume of chloroform/isoamyl alcohol $(\sim 650 \mu \mathrm{L})$. Next, 0.5 volume of $5 \mathrm{M} \mathrm{LiCl}$ was added to the supernatant, with subsequent incubation at $20^{\circ} \mathrm{C}$ for 4 hours. The RNA was selectively pelleted by centrifugation at $16,000 \times g$ for $30 \mathrm{~min}$ at $4^{\circ} \mathrm{C}$. The pellet was washed with $75 \%$ (v/v) ethanol and dried at room temperature. The RNA was solubilized in $30 \mu \mathrm{L}$ of RNase-free ultrapure water and stored in an ULT freezer at $-80^{\circ} \mathrm{C}$ for subsequent analyses.

\section{PureLink $^{\mathrm{TM}}$ RNA Mini Kit}

Approximately $100 \mathrm{mg}$ of tissue powdered in liquid nitrogen were used to obtain total RNA. After tissue disruption, $600 \mu \mathrm{L}$ of the Lysis Buffer (already containing $10 \mu \mathrm{L}$ of 2-mercaptoethanol for each $1 \mathrm{~mL}$ of buffer) was added to promote chemical lysis of the cells. Into the tissue homogenate, 0.5 volume of absolute ethanol was added and the 
mixture was vortexed. Next, $700 \mu \mathrm{L}$ of the lysate was transferred to silica spin column for the binding of RNA. The column was centrifuged at $12,000 \times g$ for 15 seconds. This procedure was carried out until all the lysate had passed through the column and the flowthrough was discarded. Subsequently, the column was washed with $700 \mu \mathrm{L}$ of Wash Buffer I and centrifuged at $12,000 \times g$ for 15 seconds to remove the residual buffer. A second wash was performed using $500 \mu \mathrm{L}$ of Wash Buffer II, and a new centrifugation under the same conditions was performed. That last step was repeated. The column was subjected to additional centrifugation to remove wash buffer residues. The silica spin column was transferred to a new $1.5 \mathrm{~mL}$ microtube for performance of RNA elution, in which $30 \mu \mathrm{L}$ of RNase-free ultrapure water was used. The obtained RNA was stored in an ULT freezer at $-80^{\circ} \mathrm{C}$.

\section{RNeasy ${ }^{\circledR}$ Plant Mini Kit}

After tissue disruption with liquid nitrogen in a mortar, $450 \mu \mathrm{L}$ of Buffer RLC (already containing $10 \mu \mathrm{L}$ of 2-mercaptoethanol for each $1 \mathrm{~mL}$ of buffer) was added to the powdered sample ( 100 mg), and the mixture was homogenized vigorously. To facilitate tissue disruption, the mixture was incubated at $56^{\circ} \mathrm{C}$ for $2 \mathrm{~min}$. The lysate was transferred to a QIAshredder spin column (lilac) and centrifuged at 14,000 $\times g$ for $2 \mathrm{~min}$. The supernatant of the flow-through was transferred to a new $2 \mathrm{~mL}$ microtube without disturbing the pellet. Half a volume $(\sim 250 \mu \mathrm{L})$ of absolute ethanol was added to each sample and the mixture was homogenized by pipetting. Next, $\sim 650 \mu \mathrm{L}$ of cleared lysate were transferred to the RNeasy ${ }^{\circledR}$ Mini spin column (pink) and immediately centrifuged at $8,000 \times g$ for 15 seconds. The flow-through was discarded, and the column was washed with $700 \mu \mathrm{L}$ of Buffer RW1 and centrifuged again at $8,000 \times g$ for 15 seconds. The flowthrough was discarded and $500 \mu \mathrm{L}$ of Buffer RPE was added to the column, followed by 
another centrifugation at $8,000 \times g$ for 15 seconds. To remove any residue from the wash buffer, an additional centrifugation at $10,000 \times g$ for 1 min was performed. The column was then transferred to a new $1.5 \mathrm{~mL}$ microtube, and the RNA was eluted from the column by addition of $30 \mu \mathrm{L}$ of RNase-free ultrapure water and centrifugation at $8,000 \times g$ for 1 min. To improve performance, the flow-through was reapplied to the column and again centrifuged. The RNA was stored in an ULT freezer at $-80^{\circ} \mathrm{C}$.

\section{TRIzol ${ }^{\circledR}$ Method}

For the extraction of total RNA, the leaf tissue $(\sim 100 \mathrm{mg})$ was powdered in a mortar using liquid nitrogen and $1 \mathrm{~mL}$ of the TRIzol ${ }^{\circledR}$ reagent (Invitrogen) was added to the sample, which was homogenized using a pestle. The entire mortar content was transferred to a $1.5 \mathrm{~mL}$ microtube and incubated for $5 \mathrm{~min}$ at room temperature. A centrifugation step at $12,000 \times g$ for $10 \mathrm{~min}$ at room temperature was performed according to the manufacturer's specifications. The whole supernatant was transferred to a new 1.5 mL microtube. Subsequently, $200 \mu \mathrm{L}$ of chloroform was added to the sample, which was shaken for 30 seconds and incubated for $5 \mathrm{~min}$ at room temperature under constant slow shaking. The sample was then centrifuged at $12,000 \times g$ for $15 \mathrm{~min}$ at $4^{\circ} \mathrm{C}$. The aqueous phase was transferred to a new $1.5 \mathrm{~mL}$ microtube. For RNA precipitation, an equal volume of isopropanol $(\sim 500 \mu \mathrm{L})$ was added to the sample, which was incubated at room temperature for $15 \mathrm{~min}$. After this step, the sample was centrifuged at $12,000 \times g$ for 10 min at $4{ }^{\circ} \mathrm{C}$ and the supernatant was discarded. The pellet was washed using $1 \mathrm{~mL}$ of $75 \%$ (v/v) ethanol. The microtube was centrifuged at $10,000 \times g$ for $5 \mathrm{~min}$ at $4{ }^{\circ} \mathrm{C}$, and the ethanol was completely removed. The pellet was dried at room temperature and the RNA was solubilized in $30 \mu \mathrm{L}$ of RNase-free ultrapure water. The RNA was stored in an ULT freezer at $-80^{\circ} \mathrm{C}$. 
Extraction buffer: $4 \mathrm{M}$ guanidine thiocyanate, $100 \mathrm{mM}$ Tris- $\mathrm{HCl}$ (pH 8.0), $25 \mathrm{mM}$ sodium citrate $\mathrm{pH}$ 8.0, 0.5\% N-laurylsarcosine, 1\% PVP (mol wt 30,000), 2\% $\beta$-mercaptoethanol (added just before use).

This method was used by Furlan et al. (2012) for RNA extraction from P. guajava tissue, but was adapted by Salzman et al. (1999). Here, we proposed a small adjustment to the initial buffer volume and amount of tissue. Initially, $900 \mu \mathrm{L}$ of extraction buffer was added to $100 \mathrm{mg}$ of powdered tissue, disrupted using liquid nitrogen in a mortar. After vigorous homogenization, the mixture was transferred to a $2 \mathrm{~mL}$ microtube and incubated for $1 \mathrm{~min}$ at room temperature. Subsequently, $750 \mu \mathrm{L}$ of chloroform/isoamyl alcohol $(24: 1, \mathrm{v} / \mathrm{v})$ was added and the sample was mixed slowly by inversion for $10 \mathrm{~min}$. Next, the sample was centrifuged at $16,000 \times g$ for $10 \mathrm{~min}$ at $4^{\circ} \mathrm{C}$. The aqueous phase $(\sim 600 \mu \mathrm{L})$ was transferred to a new $1.5 \mathrm{~mL}$ microtube and re-extracted with an equal volume of chloroform/isoamyl alcohol. After centrifugation under the same conditions as described above, the aqueous phase was recovered and transferred to a new $1.5 \mathrm{~mL}$ microtube. The RNA was then precipitated by the addition of 2 volumes of cold absolute ethanol and 0.1 volume of $5 \mathrm{M} \mathrm{NaCl}$. The sample was centrifuged at $16,000 \times g$ for 10 min at $4{ }^{\circ} \mathrm{C}$ and the formed pellet was washed with $75 \%$ ethanol. The RNA was solubilized in $800 \mu \mathrm{L}$ of RNase-free ultrapure water and an equal volume of phenol/chloroform/isoamyl alcohol (25:24:1, v/v) was added. The mixture was homogenized for $5 \mathrm{~min}$ at room temperature, then centrifuged at $12,000 \times \mathrm{g}$ for $10 \mathrm{~min}$ at room temperature. The aqueous phase was recovered and transferred to a new $1.5 \mathrm{~mL}$ microtube. The RNA was precipitated by addition of 2 volumes of ice-cold absolute ethanol and 0.1 volume of $5 \mathrm{M} \mathrm{NaCl}$, with overnight incubation at $-20^{\circ} \mathrm{C}$. The samples 
were centrifuged at $16,000 \times g$ for $10 \mathrm{~min}$ at $4^{\circ} \mathrm{C}$, and the formed pellet was washed with $75 \%(\mathrm{v} / \mathrm{v})$ ethanol. The pellet was dried at room temperature, and the RNA was solubilized in $30 \mu \mathrm{L}$ of RNase-free ultrapure water and stored in an ULT freezer at $-80^{\circ} \mathrm{C}$ for subsequent analyses.

\section{RNA Analysis (Yield, Purity and Integrity)}

RNA purity and concentration were assessed by determining the absorbance of RNA in RNase-free water at 230, 260 and $280 \mathrm{~nm}$, using a NanoDrop ND-1000 spectrophotometer (Thermo Scientific, USA). The RNA yield was calculated based on absorbance at $260 \mathrm{~nm}\left(\mathrm{~A}_{260}\right)$. The ratios $\mathrm{A}_{260} / \mathrm{A}_{280}$ and $\mathrm{A}_{260} / \mathrm{A}_{230}$ were assessed to evaluate RNA purity. RNA integrity was evaluated from the $28 \mathrm{~S}$ and $18 \mathrm{~S}$ rRNA bands in $1.0 \%$ (w/v) formaldehyde-agarose gel after electrophoresis, staining with 1:20,000 GelRed ${ }^{\circledR}$ (Biotium) and visualization with Gel Doc XR+ System (Bio-Rad, USA). Quality analysis of eighth RNA samples were assessed by TapeStation ${ }^{\circledR}$ (Agilent Technologies, USA) using RNA ScreenTape ${ }^{\circledR}$ assay, after DNase I treatment and RIN (RNA Integrity Number) were calculated.

\section{cDNA Synthesis and Reverse Transcription Polymerase Chain Reaction (RT-PCR)} Initially, the RNA was treated with RQ1 RNase-Free DNase I (Promega, USA) following the manufacturer's instructions. The first-strand cDNA was synthesized from $3.0 \mu \mathrm{g}$ of the total RNA by reverse transcriptase with random primer $(50 \mathrm{ng} / \mu \mathrm{L})$, according to instructions of the SuperScript ${ }^{\mathrm{TM}}$ IV First-Strand Synthesis System (Invitrogen, USA). The PCR reaction mix $(20 \mu \mathrm{L})$ was prepared following instructions of the PowerUp SYBR ${ }^{\circledR}$ Green Master Mix (Life Technologies, USA) in a LightCycler ${ }^{\circledR} 96$ 
453 System (Roche Life Science, Germany) thermal cycler. The cycling conditions were as 454 follows: initial denaturation at $95^{\circ} \mathrm{C}$ for $2 \mathrm{~min} ; 40$ cycles at $95^{\circ} \mathrm{C}$ for 15 seconds and $72^{\circ} \mathrm{C}$ 455 for $60 \mathrm{~s}$; and standard dissociation step from 50 to $95^{\circ} \mathrm{C}$ with increments of $0.5^{\circ} \mathrm{C}$ for 10 456 seconds. Real-time PCR analyses were performed to evaluate the quality of the RNA 457 samples from $P$. guajava tissues obtained using the $\mathrm{CTAB}_{2}$ protocol. Amplification of 458 the samples was performed using a common endogenous gene, Histone H2A, forward 459 primer 5'-AAGCCGGTCTCTCGGTCTGT-3', GCATTACCAGCCAACTCCAG-3' (Supplementary information S4).

Inhibition test

Quantitative analysis was performed to evaluate the presence of inhibitors in samples from $P$. guajava leaves obtained using the tested CTAB protocols. For this test, RNA was treated with RQ1 RNAse-Free DNAse I (Promega, USA) following the manufacturer's instructions. The first cDNA strand was synthesized from $5.0 \mu \mathrm{L}$ of the total RNA by reverse transcriptase with random primer (50 ng/ $\mu \mathrm{L})$, according to the instructions of the SuperScript ${ }^{\mathrm{TM}}$ III First-Strand Synthesis System (Invitrogen, USA). qRT-PCR amplification was performed using a common endogenous gene, Histone H2A. Standard curves were constructed for each sample, in which the largest volume of cDNA was $1 \mu \mathrm{L}(\sim 100 \mathrm{ng}$ per reaction) and the lowest was $0.125 \mu \mathrm{L}(\sim 12.5 \mathrm{ng}$ per reaction), following a dilution factor of 1:2. From the Ct values obtained for each dilution, a graph was plotted relating $\mathrm{Ct}$ vs. $\log$ (cDNA volume), and the linear equation was obtained for each sample. Using the $\mathrm{Ct}$ value of the lowest dilution, a curve was estimated in which the efficiency would be optimal, increasing one $\mathrm{Ct}$ value per cycle. 


\section{Declarations}

478 Ethics approval and consent to participate

$479 \quad$ Not applicable

480

481 Consent for publication

$482 \quad$ Not applicable

483

484 Availability of data and materials

485 The datasets used and/or analysed during the current study are available from the 486 corresponding author on reasonable request.

487

488 Competing interests

489 The authors declare that they have no competing interests.

490

491 Funding

492 The authors are grateful to the Brazilian funding agencies Conselho Nacional de Pesquisa 493 (CNPq), Coordenação de Aperfeiçoamento de Pessoal de Nível Superior (CAPES) 494 Finance Code 001, and Fundação de Amparo à Pesquisa do Espírito Santo (FAPES) for 495 providing support to this study.

496

497 Authors' contributions

498 Carpinetti PA, Ferreira MFS and Ferreira A designed the study. Carpinetti PA, Fioresi

499 VS, Cruz TI, Almeida F and Canal D performed the protocol evaluations. Carpinetti PA, 500 Fioresi VS and Almeida F carried out the extraction of different tissues, genotypes and 
501

502

503

504

505

506

507

508

509

510

511

512

513

514

515

516

517

518

519

520

521

522

523

524

525

526

527

528

529

530

samples under stress. Fioresi VS and Carpinetti PA are responsible for the qRT-PCR analysis. Carpinetti PA, Ferreira MFS, Fioresi VS, Almeida F and Ferreira A wrote the manuscript. All authors have read and approved the final manuscript.

\section{Acknowledgments}

Not applicable

7

\section{References}

1. Clark MS. Plant Molecular Biology — A Laboratory Manual. Berlin: Springer Science; 2013.

2. Farrell RE. RNA Methodologies. In: Encyclopedia of Molecular Cell Biology and Molecular Medicine. Weinheim, Germany: Wiley-VCH Verlag GmbH \& Co. KGaA; 2011. doi:10.1002/3527600906.mcb.201100008.

3. Gambino G, Perrone I, Gribaudo I. A Rapid and effective method for RNA extraction from different tissues of grapevine and other woody plants. Phytochem Anal. 2008;19:520-5. doi:10.1002/pca.1078.

4. Ghawana S, Paul A, Kumar H, Kumar A, Singh H, Bhardwaj PK, et al. An RNA isolation system for plant tissues rich in secondary metabolites. BMC Res Notes. 2011;4:85. doi:10.1186/1756-0500-4-85.

5. Wang G, Wang G, Zhang X, Wang F, Song R. Isolation of High Quality RNA from Cereal Seeds Containing High Levels of Starch. Phytochem Anal. 2012;23:159-63. doi:10.1002/pca.1337.

6. Kumar A, Singh K. Isolation of High Quality RNA from Phyllanthus emblica and Its Evaluation by Downstream Applications. Mol Biotechnol. 2012;52:269-75. doi:10.1007/s12033-011-9492-5.

7. Deepa K, Sheeja TE, Santhi R, Sasikumar B, Cyriac A, Deepesh P V., et al. A simple and efficient protocol for isolation of high quality functional RNA from different tissues of turmeric (Curcuma longa L.). Physiol Mol Biol Plants. 2014;20:263-71. doi:10.1007/s12298-013-0218-y.

8. FAO. Food and Agriculture Organization of the United Nations. Statistics Division FAOSTAT. 2018. http://www.fao.org/faostat/en/\#data/QC. Accessed 7 Aug 2020.

9. Joseph, B., \& Priya R. REVIEW ON NUTRITIONAL, MEDICINAL AND PHARMACOLOGICAL PROPERTIES OF GUAVA (PSIDIUM GUAJAVA LINN.). Int J Pharma Bio Sci. 2011;2:53-69.

10. Naseer S, Hussain S, Naeem N, Pervaiz M, Rahman M. The phytochemistry and medicinal value of Psidium guajava (guava). Clin Phytoscience. 2018;4:32. doi:10.1186/s40816-018-0093-8. 
532 J Cell Tissue Res. 2008;8:1313-6.

533 http://citeseerx.ist.psu.edu/viewdoc/download?doi=10.1.1.1071.4609\&rep=rep1\&type=pdf.

534 12. Choi JH, Park BH, Kim HG, Hwang YP, Han EH, Jin SW, et al. Inhibitory effect of Psidium guajava 535 water extract in the development of 2,4-dinitrochlorobenzene-induced atopic dermatitis in NC/Nga mice.

536 Food Chem Toxicol. 2012;50:2923-9. doi:10.1016/j.fct.2012.04.044.

537 13. Tella T, Masola B, Mukaratirwa S. The effect of Psidium guajava aqueous leaf extract on liver

538 glycogen enzymes, hormone sensitive lipase and serum lipid profile in diabetic rats. Biomed

539 Pharmacother. 2019;109:2441-6. doi:10.1016/j.biopha.2018.11.137.

540 14. Birdi T, Gupta P. Psidium guajava leaf extract prevents intestinal colonization of Citrobacter

541 rodentium in the mouse model. J Ayurveda Integr Med. 2015;6:50. doi:10.4103/0975-9476.146557.

542 15. Bontempo P, Doto A, Miceli M, Mita L, Benedetti R, Nebbioso A, et al. Psidium guajava L. anti-

543 neoplastic effects: induction of apoptosis and cell differentiation. Cell Prolif. 2012;45:22-31.

544 doi:10.1111/j.1365-2184.2011.00797.x.

545 16. Dutta S, Das S. A study of the anti-inflammatory effect of the leaves of Psidium guajava Linn. on 546 experimental animal models. Pharmacognosy Res. 2010;2:313. doi:10.4103/0974-8490.72331.

547 17. Lins TH, Santos Veríssimo RCS, Evangelista Santos RF, Assis Bastos ML de, Correia Bernardo RC, 548 Alvino V, et al. Evaluation of antimicrobial activity of psidium guajava species. BMC Proc. 2014;8:P79. 549 doi:10.1186/1753-6561-8-S4-P79.

550 18. Rai MK, Asthana P, Jaiswal VS, Jaiswal U. Biotechnological advances in guava (Psidium guajava

551 L.): recent developments and prospects for further research. Trees. 2010;24:1-12. doi:10.1007/s00468-

552 009-0384-2.

553 19. Ritter E. GUAVA BIOTECHNOLOGIES, GENOMIC ACHIEVEMENTS AND FUTURE NEEDS.

554 Acta Hortic. 2012;:131-40. doi:10.17660/ActaHortic.2012.959.16.

555 20. Nimisha S, Kherwar D, Ajay KM, Singh B, Usha K. Molecular breeding to improve guava (Psidium

556 guajava L.): Current status and future prospective. Sci Hortic (Amsterdam). 2013;164:578-88.

557 doi:10.1016/j.scienta.2013.10.017.

558 21. Jones AS. The isolation of bacterial nucleic acids using cetyltrimethylammonium bromide (Cetavlon).

559 Biochim Biophys Acta. 1953;10:607-12. doi:10.1016/0006-3002(53)90304-7.

560 22. Dellacorte C. Isolation of nucleic acids from the sea anemone Condylactis gigantea (Cnidaria:

561 Anthozoa). Tissue Cell. 1994;26:613-9. doi:10.1016/0040-8166(94)90013-2.

562 23. Shahjahan RM, Hughes KJ, Leopold RA, DeVault JD. Lower incubation temperature increases yield

563 of insect genomic DNA isolated by the CTAB method. Biotechniques. 1995;19:332-4.

564 http://www.ncbi.nlm.nih.gov/pubmed/7495537. 

DNA from clinical samples for PCR amplification. Med Mycol. 1999;37:69-73.

567 doi:10.1080/02681219980000101.

568 25. Zhao L, Ding Q, Zeng J, Wang F-R, Zhang J, Fan S-J, et al. An Improved CTAB-Ammonium Acetate 569 Method for Total RNA Isolation from Cotton. Phytochem Anal. 2012;23:647-50. doi:10.1002/pca.2368.

570 26. Arseneau J-R, Steeves R, Laflamme M. Modified low-salt CTAB extraction of high-quality DNA 571 from contaminant-rich tissues. Mol Ecol Resour. 2017;17:686-93. doi:10.1111/1755-0998.12616.

572 27. Porebski S, Bailey LG, Baum BR. Modification of a CTAB DNA extraction protocol for plants 573 containing high polysaccharide and polyphenol components. Plant Mol Biol Report. 1997;15:8-15. 574 doi:10.1007/BF02772108.

575 28. Gehrig HH, Winter K, Cushman J, Borland A, Taybi T. An improved RNA isolation method for 576 succulent plant species rich in polyphenols and polysaccharides. Plant Mol Biol Report. 2000;18:369-76. 577 doi:10.1007/BF02825065.

578 29. Zeng Y, Yang T. RNA isolation from highly viscous samples rich in polyphenols and 579 polysaccharides. Plant Mol Biol Report. 2002;20:417-417. doi:10.1007/BF02772130. 30. Zoubenko O V., Allison LA, Svab Z, Maliga P. Efficient targeting of foreign genes into the tobacco plastid genome. Nucleic Acids Res. 1994;22:3819-24. doi:10.1093/nar/22.19.3819. 31. Baldridge, G.D., O’Neill, N.R. \& Samac DA. Alfalfa (Medicago sativa L.) resistance to the rootlesion nematode, Pratylenchus penetrans: defense-response gene mRNA and isoflavonoid phytoalexin levels in roots. Plant Mol Biol. 1998;38:999-1010. Triacontanol-Regulated Genes in Rice (Oryza sativa L.): Possible Role of Triacontanol as a Plant Growth Stimulator. Plant Cell Physiol. 2002;43:869-76. doi:10.1093/pcp/pcf100. 33. Blanca J, Cañizares J, Roig C, Ziarsolo P, Nuez F, Picó B. Transcriptome characterization and high throughput SSRs and SNPs discovery in Cucurbita pepo (Cucurbitaceae). BMC Genomics. 2011;12:104. doi:10.1186/1471-2164-12-104. 34. Sundell D, Street NR, Kumar M, Mellerowicz EJ, Kucukoglu M, Johnsson C, et al. AspWood: HighSpatial-Resolution Transcriptome Profiles Reveal Uncharacterized Modularity of Wood Formation in Populus tremula. Plant Cell. 2017;29:1585-604. doi:10.1105/tpc.17.00153. 35. Liu L, Han R, Yu N, Zhang W, Xing L, Xie D, et al. A method for extracting high-quality total RNA from plant rich in polysaccharides and polyphenols using Dendrobium huoshanense. PLoS One. 2018;13:e0196592. doi:10.1371/journal.pone.0196592. 36. Arruabarrena A, Benítez-Galeano MJ, Giambiasi M, Bertalmío A, Colina R, Hernández-Rodríguez L. 598 Application of a simple and affordable protocol for isolating plant total nucleic acids for RNA and DNA 599 virus detection. J Virol Methods. 2016;237:14-7. doi:10.1016/j.jviromet.2016.08.011. 
37. Furlan CM, Zanotta S, Salatino A. cDNA-AFLP analysis of Psidium guajava L. cultivars under water stress and mechanical injury: methodological implications. Brazilian J Plant Physiol. 2012;24:29-36. doi:10.1590/S1677-04202012000100005.

38. Flores G, Wu S-B, Negrin A, Kennelly EJ. Chemical composition and antioxidant activity of seven cultivars of guava (Psidium guajava) fruits. Food Chem. 2015;170:327-35. doi:10.1016/j.foodchem.2014.08.076.

39. Ramírez IM., Rodríguez NN., Valdés-Infante, Juliette; Capote M, Becker D., Rohde W. Isolation of genomic DNA from the tropical fruit trees avocado, coconut, guava and mango for PCR-based DNA marker application. Cultiv Trop. 2004;25:33-8. https://www.redalyc.org/pdf/1932/193230179006.pdf. 40. Jaakola L, Pirttilä AM, Halonen M, Hohtola A. Isolation of High Quality RNA from Bilberry (Vaccinium myrtillus L.) Fruit. Mol Biotechnol. 2001;19:201-4. doi:10.1385/MB:19:2:201.

41. Guzman F, Kulcheski FR, Turchetto-Zolet AC, Margis R. De novo assembly of Eugenia uniflora L. transcriptome and identification of genes from the terpenoid biosynthesis pathway. Plant Sci. 2014;229:238-46. doi:10.1016/j.plantsci.2014.10.003.

42. Vining KJ, Romanel E, Jones RC, Klocko A, Alves-Ferreira M, Hefer CA, et al. The floral transcriptome of Eucalyptus grandis. New Phytol. 2015;206:1406-22. doi:10.1111/nph.13077.

43. Favreau B, Denis M, Ployet R, Mounet F, Peireira da Silva H, Franceschini L, et al. Distinct leaf transcriptomic response of water deficient Eucalyptus grandis submitted to potassium and sodium fertilization. PLoS One. 2019;14:e0218528. doi:10.1371/journal.pone.0218528.

44. Guillemaut P, Maréchal-Drouard L. Isolation of plant DNA: A fast, inexpensive, and reliable method. Plant Mol Biol Report. 1992;10:60-5.

45. CRUZ MD LA, WHITKUS R, MOTA-BRAVO L. Tropical tree DNA isolation and amplification. Mol Ecol. 1995;4:787-90.

46. Pandey RN, Adams RP, Flournoy LE. Inhibition of random amplified polymorphic DNAs (RAPDs) by plant polysaccharides. Plant Mol Biol Report. 1996;14:17-22.

47. Chang S, Puryear J, Cairney J. A Simple and Efficient Method for Isolating RNA from Pine Trees. Plant Mol Biol Report. 1993;11:113-6.

48. Nadiya F, Anjali N, Gangaprasad A, Sabu KK. High-quality RNA extraction from small cardamom tissues rich in polysaccharides and polyphenols. Anal Biochem. 2015;485:25-7.

49. Wong L-M, Silvaraj S, Phoon L-Q. An Optimised High-Salt CTAB Protocol for Both DNA and RNA Isolation from Succulent Stems of Hylocereus sp. J Med Bioeng. 2014;3:236-40.

50. Sajeevan RS, Shivanna MB, Nataraja KN. An Efficient Protocol for Total RNA Isolation from Healthy and Stressed Tissues of Mulberry (\&amp;lt;i\&amp;gt;Morus\&amp;lt;/i\&amp;gt; sp.) and Other Species. Am J Plant Sci. 2014;05:2057-65. doi:10.4236/ajps.2014.513221. 

Antioxidative Defense Mechanism in Plants under Stressful Conditions. J Bot. 2012;2012:1-26. doi:10.1155/2012/217037.

637 52. Lal L, Sahoo R, Gupta RK, Sharma P, Kumar S. RNA isolation from high-phenolic tea leaves and 638 apical buds. Plant Mol Biol Report. 2001;19:181-181. doi:10.1007/BF02772161. 53. Schroeder A, Mueller O, Stocker S, Salowsky R, Leiber M, Gassmann M, et al. The RIN: an RNA 640 integrity number for assigning integrity values to RNA measurements. BMC Mol Biol. 2006;7:3.

641 doi:10.1186/1471-2199-7-3.

642 54. Behnam B, Bohorquez-Chaux A, Castaneda-Mendez OF, Tsuji H, Ishitani M, Becerra Lopez-Lavalle

643 LA. An optimized isolation protocol yields high-quality RNA from cassava tissues Manihot esculenta.

644 FEBS Open Bio. 2019;9:814-25. doi:10.1002/2211-5463.12561.

645 55. Meher, Shivakrishna P, Ashok Reddy K, Manohar Rao D. Effect of PEG-6000 imposed drought stress 646 on RNA content, relative water content (RWC), and chlorophyll content in peanut leaves and roots. Saudi 647 J Biol Sci. 2018;25:285-9. doi:10.1016/j.sjbs.2017.04.008.

648 56. Rossen L, Nørskov P, Holmstrøm K, Rasmussen OF. Inhibition of PCR by components of food 649 samples, microbial diagnostic assays and DNA-extraction solutions. Int J Food Microbiol. 1992;17:3765045.

651 57. Wilson IG. Inhibition and facilitation of nucleic acid amplification. Appl Environ Microbiol. $652 \quad 1997 ; 63: 3741-51$.

653 58. Opel KL, Chung D, McCord BR. A study of PCR inhibition mechanisms using real time PCR. J 654 Forensic Sci. 2010;55:25-33.

655 59. Saulnier P, Andremont A. Detection of genes in feces by booster polymerase chain reaction. J Clin 656 Microbiol. 1992;30:2080-3.

657 60. Powell HA, Gooding CM, Garrett SD, Lund BM, Mckee RA. Proteinase inhibition of the detection of 658 Listeria monocytogenes in milk using the polymerase chain reaction. Lett Appl Microbiol. 1994;18:5965961.

660 61. Katcher HL, Schwartz I. A distinctive property of Tth DNA polymerase: enzymatic amplification in 661 the presence of phenol. Biotechniques. 1994;16:84.

662 62. Sidstedt M, Rådström P, Hedman J. PCR inhibition in qPCR, dPCR and MPS —-mechanisms and 663 solutions. Anal Bioanal Chem. 2020;412:2009-23. doi:10.1007/s00216-020-02490-2. 
Analys is of RNA yield and purity of in vitro plant samples from Psidium guineense

\begin{tabular}{cccc}
\hline Samples & Yield (ng/ $\boldsymbol{L L})$ & A260/A280 ratio & A260/A230 ratio \\
\hline 1 & 141.43 & 2.12 & 2.15 \\
2 & 185.18 & 2.08 & 2.15 \\
3 & 336.43 & 2.15 & 2.15 \\
4 & 235.04 & 2.06 & 2.11 \\
5 & 330.05 & 2.19 & 2.28 \\
\hline Mean & $\mathbf{2 4 5 . 6 3}$ & $\mathbf{2 . 1 2}$ & $\mathbf{2 . 1 7}$ \\
SD & $\mathbf{7 7 . 4 5}$ & $\mathbf{0 . 0 5}$ & $\mathbf{0 . 0 6}$ \\
\hline
\end{tabular}

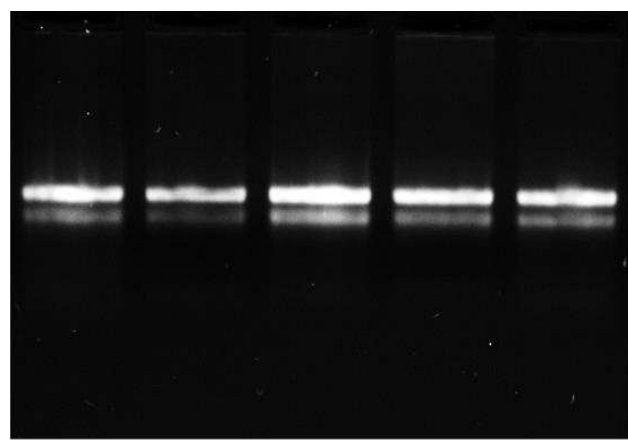

Supplementary information S1 - Analysis of RNA samples from $P$. guineense. Table summarizing the quantification of the RNA samples in a NanoDrop spectrophotometer (Thermo Fischer, USA), as well as the ratios $\mathrm{A}_{260} / \mathrm{A}_{280}$ and $\mathrm{A}_{260} / \mathrm{A}_{230}$. Denaturing agarose gel $(1 \%)$ electrophoresis of total extracted RNA $(2 \mu \mathrm{L})$ stained with GelRed (Biotium, USA).

RNA yield and purity of s amples used in qRT-PCR inhibition test

\begin{tabular}{|c|c|c|c|c|}
\hline \multicolumn{2}{|c|}{ Samples } & \multirow{2}{*}{$\frac{\text { Yield }(\mathbf{n g} / \boldsymbol{\mu L})}{294.2}$} & \multirow{2}{*}{$\frac{\mathbf{A}_{\mathbf{2 6 0}} / \mathbf{A}_{\mathbf{2 8 0}} \text { ratio }}{2.07}$} & \multirow{2}{*}{$\frac{\mathbf{A}_{\mathbf{2 6 0}} / \mathbf{A}_{\mathbf{2 3 0}} \text { ratio }}{2.53}$} \\
\hline \multirow{6}{*}{ 苞 } & A & & & \\
\hline & B & 260.5 & 2.16 & 2.40 \\
\hline & $\mathrm{C}$ & 339.6 & 2.13 & 2.49 \\
\hline & $\mathrm{D}$ & 460.8 & 2.13 & 2.51 \\
\hline & E & 339.6 & 2.13 & 2.49 \\
\hline & F & 301.7 & 2.17 & 2.51 \\
\hline \multirow{6}{*}{ 艺 } & A & 420.12 & 2.23 & 2.42 \\
\hline & B & 525.69 & 2.04 & 2.45 \\
\hline & $\mathrm{C}$ & 378.84 & 2.22 & 2.17 \\
\hline & $\mathrm{D}$ & 339.81 & 2.23 & 2.27 \\
\hline & E & 435.11 & 2.12 & 2.47 \\
\hline & $\mathrm{F}$ & 622.22 & 2.19 & 2.37 \\
\hline & Mean & 396.9 & 2.16 & 2.42 \\
\hline & SD & 99.45 & 0.06 & 0.10 \\
\hline
\end{tabular}

Supplementary information S2 - RNA yield and purity of samples used in qRT-PCR inhibition test. Table summarizing the quantification of the RNA samples in a NanoDrop spectrophotometer (Thermo Fischer, USA), as well as the ratios $\mathrm{A}_{260} / \mathrm{A}_{280}$ and $\mathrm{A}_{260} / \mathrm{A}_{230}$. 
Supplementary information S3 - Five different tissues from $P$. guajava used to obtain the total RNA. Flower bud (BF); Immature leaf (IL); Young leaf (YL); Mature leaf (ML); and Root (R).
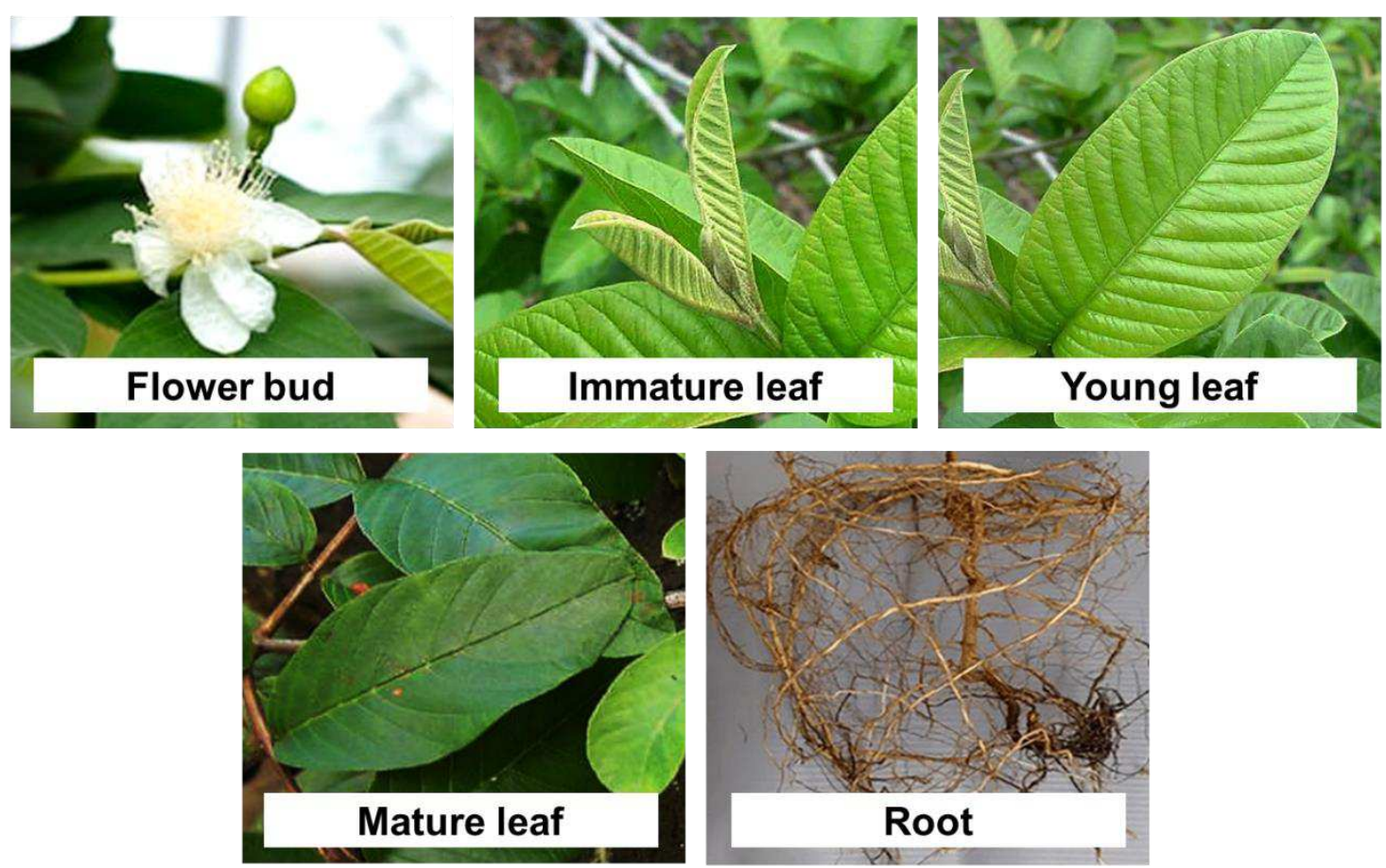

673

674

675

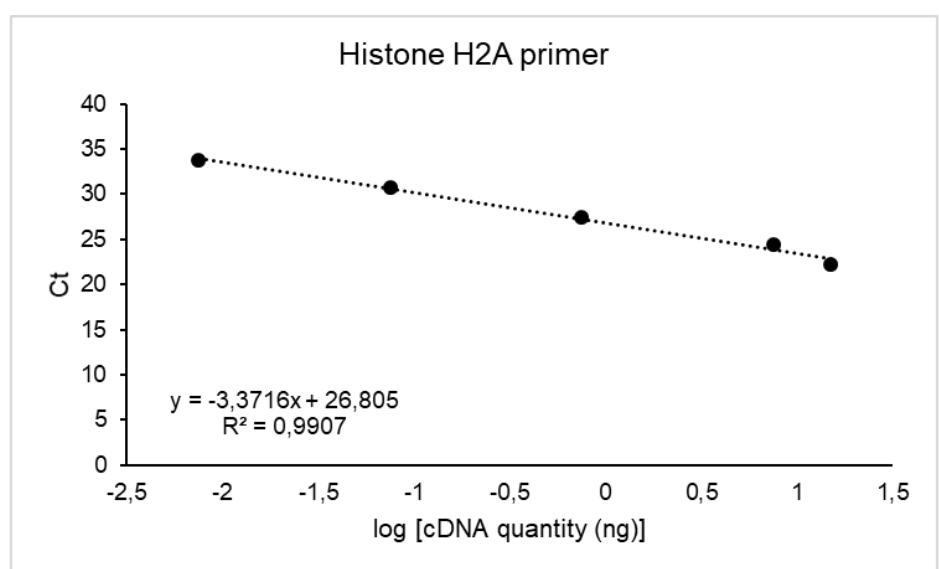

Supplementary information S4 - Primer efficiency. For the primer efficiency analysis, standard curves were constructed with cDNA quantities of $50 \mathrm{ng}$ (highest), $25 \mathrm{ng}, 2.5$ ng, $0.25 \mathrm{ng}$ and $0.025 \mathrm{ng}$ (lowest). The efficiency was $98 \%$. 
Figures

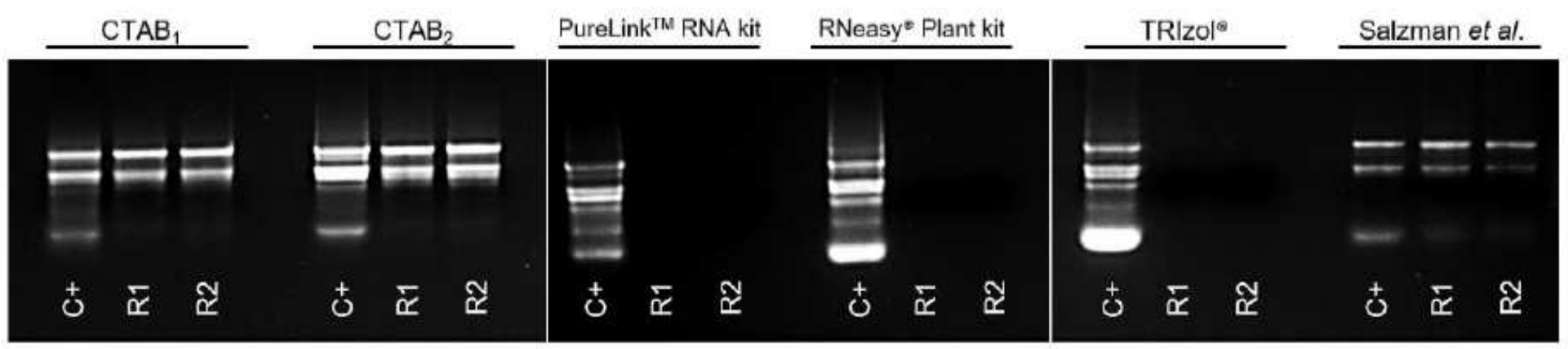

Figure 1

Qualitative analysis of RNA by electrophoresis. 

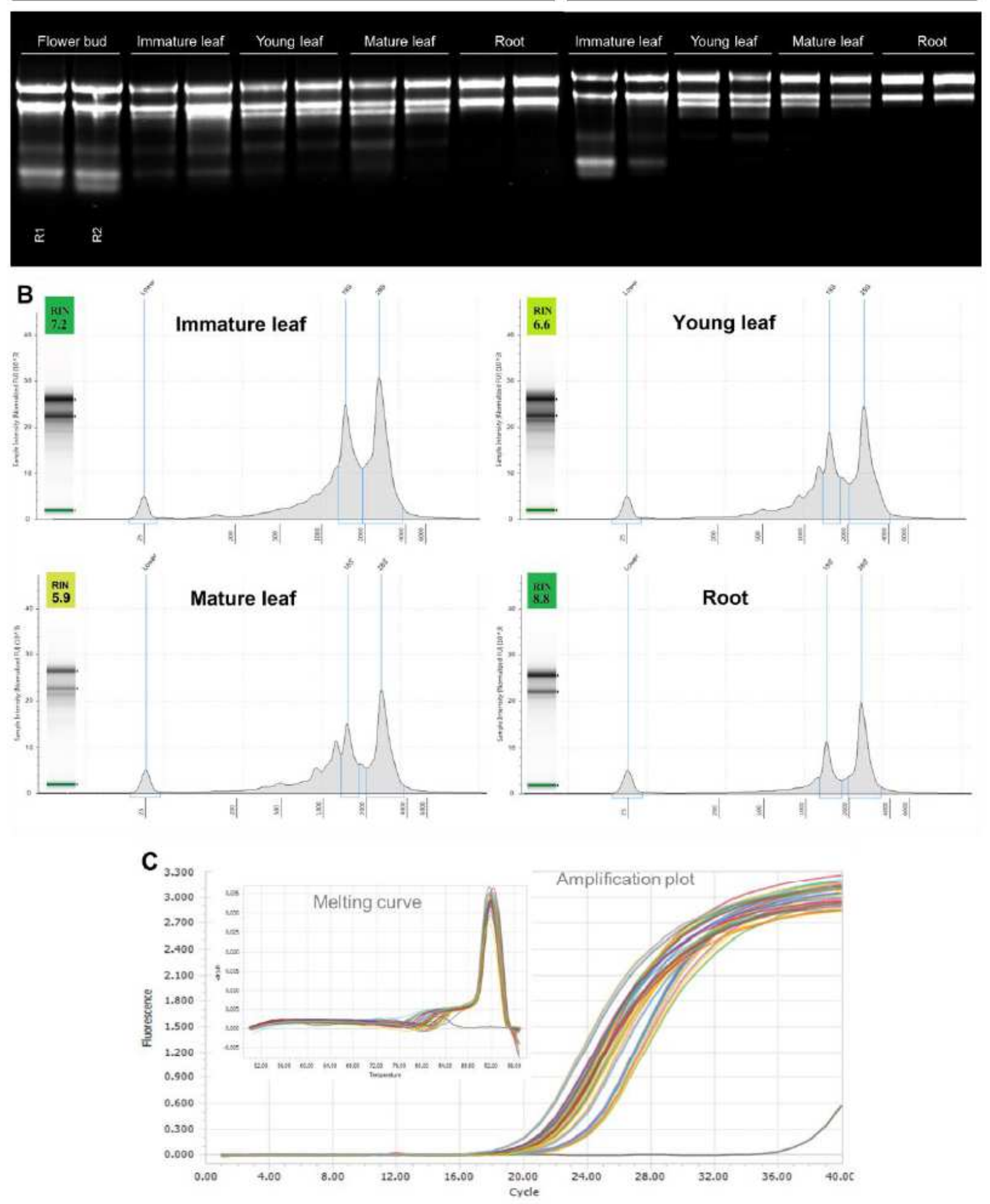

Figure 2

Qualitative analysis of RNA from different tissues. 
CTAB $_{1}$-A

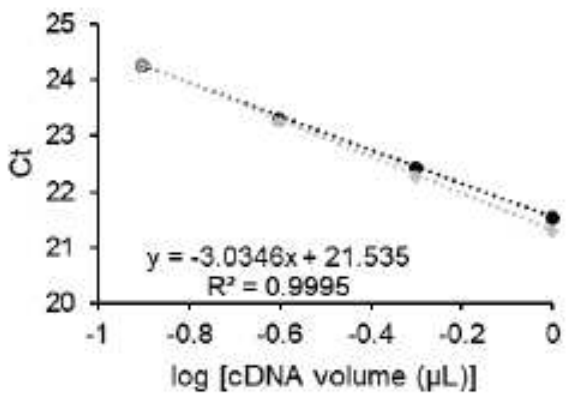

CTAB $_{1}$-D

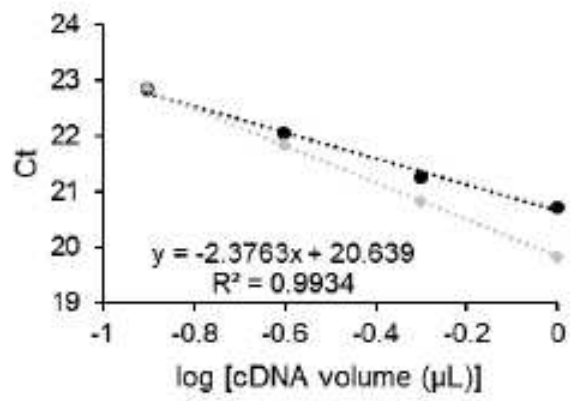

$\mathrm{CTAB}_{2}-\mathrm{A}$

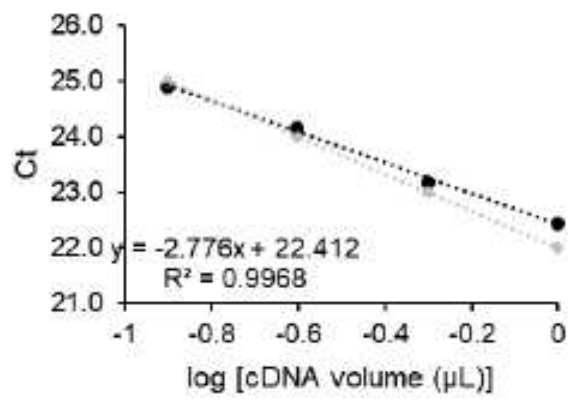

$\mathrm{CTAB}_{2}$-D

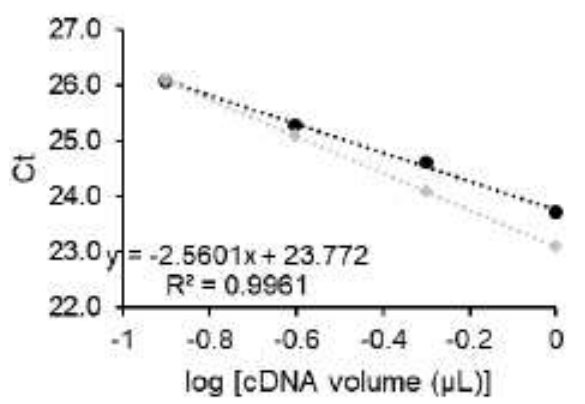

CTAB $_{1}$-B

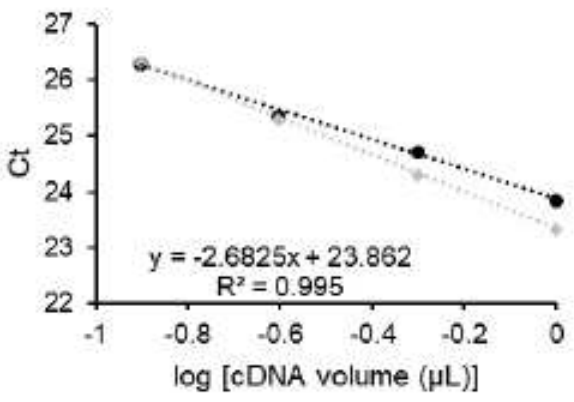

$\mathrm{CTAB}_{1}-\mathrm{E}$

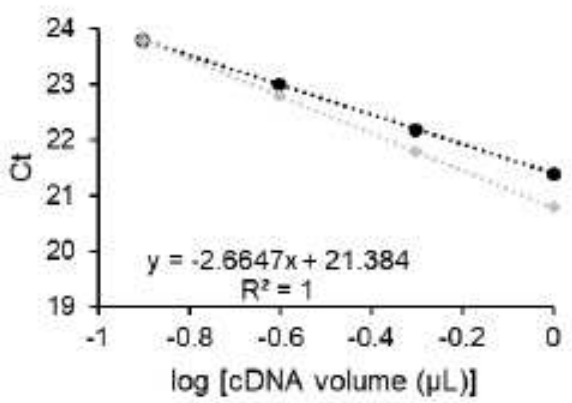

$\mathrm{CTAB}_{2}-\mathrm{B}$

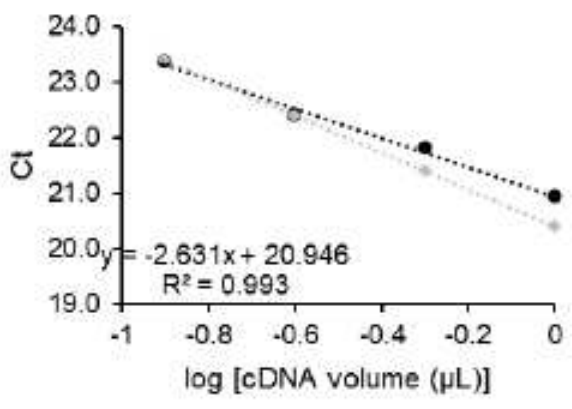

$\mathrm{CTAB}_{2}-\mathrm{E}$

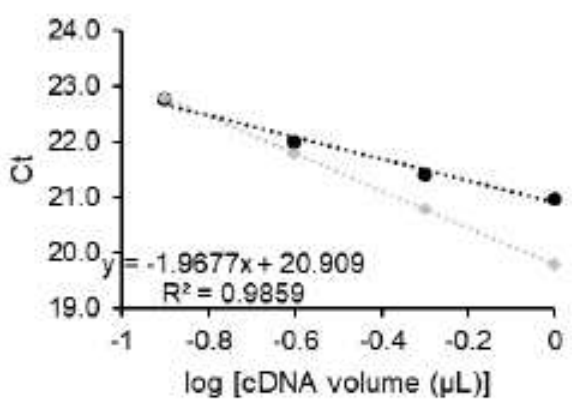

CTAB $_{1}$-C

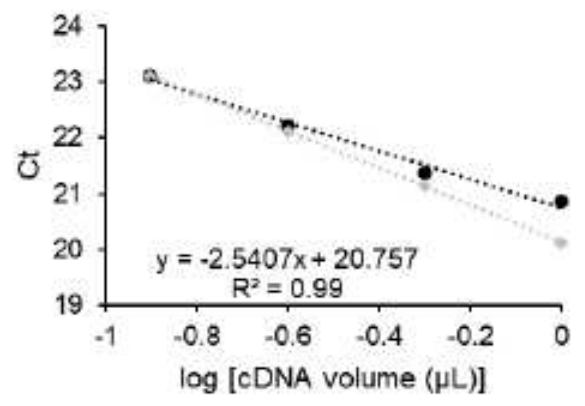

CTAB $_{1}-\mathrm{F}$

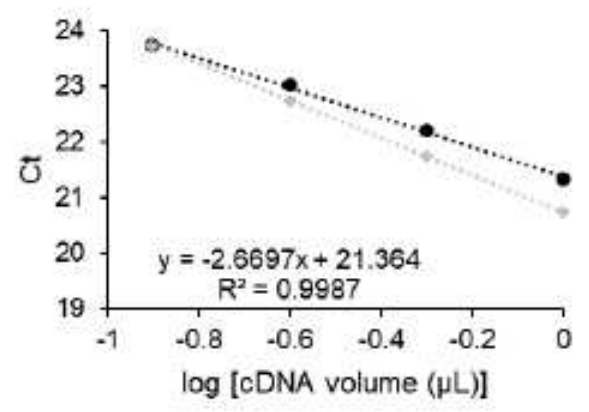

$\mathrm{CTAB}_{2}-\mathrm{C}$

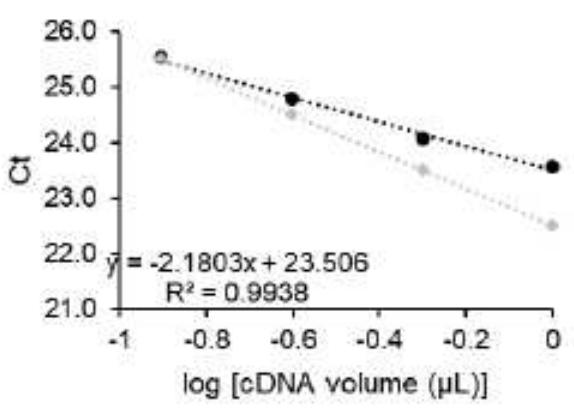

$\mathrm{CTAB}_{2}-\mathrm{F}$

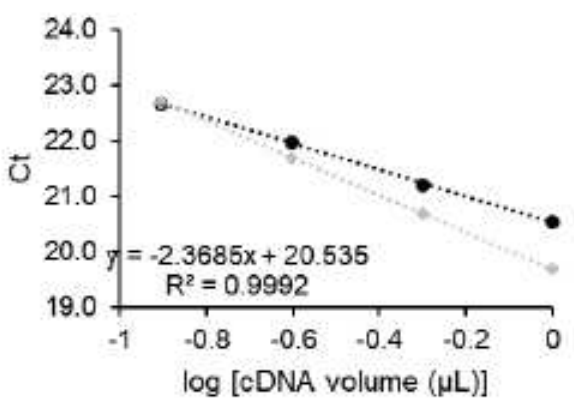

\section{Figure 3}

Quantitative analysis by qRT-PCR to compare CTAB methods. 